\title{
PENGARUH PELATIHAN PLYOMETRIC SQUAT JUMP DAN DEPTH JUMP TERHADAP DAYA LEDAK PADA PEMAIN BOLA VOLI DI SMP NEGERI 5 JEMBER
}

\author{
Bahtiar Hari Hardovi \\ Program Studi Pendidikan Olahraga Fakultas Keguruan dan Ilmu Pendidikan \\ Universitas Muhammadiyah Jember \\ email : $\underline{\text { bahtiarharihardovi@unmuhjember.ac.id }}$
}

\begin{abstract}
ABSTRAK
Tujuan dari penelitian ini yaitu untuk mengetahui pegaruh latihan squat jump dan depth jump terhadap daya ledak. Penelitian ini menggunakan metode quasy experiment dengan pemberian pretest dan posttest. Subjek penelitian yaitu atlet bola voli putra di SMPN 5 Jember berjumlah 12 orang yang dibagi menjadi dua kelompok dengan metode ordinal pairing. Data diperoleh dengan menggunakan pretest dan posttest dilakukan seminggu 3 kali selama 2 bulan. Alat yang digunakan untuk mengukur hasil tinggi loncatan dalam penelitian ini yaitu jump meter digital. Hasil penelitian ini menunjukkan tidak terdapat perbedaan yang signifikan antara kedua metode latihan squat jump dan depth jump dalam meningkatkan daya ledak otot tungkai pada pemain bola voli SMPN 5 Jember. Simpulan dari penelitian ini adalah:(1) pelatihan split squat jump berpengaruh signifikan terhadap peningkatan daya ledak otot tungkai pada pemain bola voli SMPN 5 Jember $(\mathrm{sig}=0,001)$; (2) pelatihan depth jump berpengaruh signifikan terhadap peningkatan daya ledak otot tungkai pada pemain bola voli SMPN 5 Jember $(\operatorname{sig}=0,029)$; (3) pelatihan split squat jump lebih kecil $(\mathrm{sig}=0,001)$ daripada latihan depth jump $(\mathrm{sig}=0,029)$, sedangkan presentase peningkatan power otot tungkai latihan split jump diperoleh persentase $13,17 \%$ dan squat jump diperoleh $12,87 \%$
\end{abstract}

Kata Kunci : plyometric, split squat jump, depth jump

\section{ABSTRACT}

The purpose of this study was to determine the effect of squat jump and depth jump exercises on explosive power. This study implemented a quasi-experiment with a pre-test and posttest procedure. The subject of this study is male volleyball team of SMP N 5 Jember. The results of the research indicates that there is no significant difference between the two training methods in improving muscle leg power of the volleyball team of SMP N 5 Jember. The findings were interpreted as follows: (1) the squat jump training method significantly influenced the explosive power of leg of the volleyball team of SMP N 5 Jember ( jump training method significantly influenced the explosive power of leg of the volleyball team of SMP N 5 Jember (sig $=0,029<a=0.05)$; (3) the squat jump training method slightly gain higher power of leg than the depth jump training method.

Keywords : plyometric, split squat jump, depth jump

$凶$ Alamat korespondensi:

E-mail: bahtiarharihardovi@unmuhjember.ac.id

(C) 2019 IKIP BUDI UTOMO MALANG Info Artikel

Dikirim : : 4 Oktober 2019

Diterima $\quad: 21$ Oktober 2019

DOI $\quad$ : https://doi.org/10.33503/jp.jok.v3i1.584

Bahtiar Hari Hardovi. Pengaruh Pelatihan Plyometric Squat Jump Dan Depth Jump Terhadap Daya Ledak Pada Pemain Bola Voli Di Smp Negeri 5 Jember 


\section{PENDAHULUAN}

Bola voli merupakan cabang olahraga yang populer di dunia. Cabang olahraga ini dapat dimainkan berbagai kelompok umur mulai dari usia dini sampai dewasa. Seiring dengan perkembangannya, olahraga ini dapat dilakukan dengan tujuan rekreasional atau untuk berprestasi. Berkaitan dengan olahraga prestasi, maka diperlukan bentuk latihan untuk peningkatan prestasi atlet. Pada cabang olahraga bola voli, semua anggota tubuh digunakan dalam gerakan-gerakan dalam permaianan. Oleh karena itu, semua komponen tubuh sangat diperlukan dalam melakukan keterampilan gerak teknik dasar dan fisik yang baik. Permainan bola voli yaitu permainan yang terdiri dari 6 pemain pada setiap regunya dengan tujuan memukulbolakearea lawan sehingga tidak bisa dikembalikan menurut M. Riza (Mushofi, 2017).

Fungsi utama latihan atau training dalam olahraga adalah agar tubuh mampu mengerahkan tenaga untuk mencapai hasil yang maksimal (Ruswan, 2008). Latihan dapat diartikan sebagai proses penyesuaian tubuh terhadap tuntutan kerja yang lebih berat dalam mempersiapkan diri dalam menghadapi situasi pertandingan.Kondisi fisik adalah suatu kesatuan utuh dari komponen-komponen yang tidak dapat dipisahkan baik peningkatan maupun pemeliharaannya (Setiawan, 2013). Artinya bahwa setiap usaha peningkatan kondisi fisik harus mengembangkan semua komponen tersebut walaupun perlu dilakukan prioritas.

Spilt squat jump merupakan bentuk latihan plyometric yang dapat diterapkan pada cabang olahraga bolavoli (Santosa, 2015). Latihan ini sangat tepat untuk peningkatan otot tungkai dalam melompat keatas tanpa awalan seperti gerakan blok dalam permainan bolavoli yang dilakukan tanpa awalan. Hanya meloncat keatas mengandalkan kekuatan otot tungkai, karena gerakan dari latihan ini dari latihan split squat jump ini yaitu dengan loncat setinggi dan selurus mungkin dengan mengayun lengan untuk menambah pengangkatan. Saat mendarat kembali seperti posisi semula kemudian lekuk lutut depan untuk meredam kejutan dan setelah posisi stabil lakukan gaerakan seperti awal.

Sedangkan latihan depth jump juga merupakan salah satu bentuk latihan yang bertujuan untuk meningkakan latihan otot tungkai (Hidayat, 2018). Latihan ini berfungsi untuk membina kekuatan tungkai, konsentrasi, kecepatan gerak dan 
loncatan ke atas kedepan yang dibutuhkan dalam permainan bolavoli karena bentuk latihan depth jump ini yaitu terjun dari kotak ke tanah tanpa melompat, mendarat ketanah dengan kedua kaki dan lutut bengkok untuk meredam kejutan dari fase pendaratan. Setalah mendarat segera lakukan lompatan dengan mengayun lengan ke atas dan menjongkokkan badan (Perikles, Mintarto, \& Hasan, 2016).

Berdasarkan observasi awal ternyata sebagian besar atlet belum pernah melakukan bentuk latihan squat jump dan depth jump. Dari uraian diatas maka perlu dilakukan bentuk latihan tersebut untuk meningkatkan kekuatan otot tungkai guna untuk meningkatkan power pada atlet pemain bola voli di SMP N 5 Jember (Adams, O’Shea, O’Shea, \& Climstein, 1992).

(1) Definisi operasional (a). Split squat jump. Split squat jump merupakan suatu bentuk latihan yaitu berdiri dengan satu kaki diarahkan dengan kedepan dan yang lain di arahkan ke belakang, garis tengah tubuh seperti ketika melakukan langkah panjang kaki di tekuk 90 derajat pada lutut, lompat setinggi dan selurus mungkin dengan menggunakan ayunan lengan ke atas untuk menambah pengangkatan. Saat mendarat kembali pada posisi semula, tekuk lutut depan untuk meredam kejutan setelah stabil kemudian lakukan lompatan yang sama. (b). Depth jump. Depth jump merupakan bentuk plyometric yang menggunakan kotak setinggi 12 inchi $(30 \mathrm{~cm})$ (Barr \& Nolte, 2011). Posisi awal berdiri pada setiap kotak dengan ujung kaki sedikit keluar dari tepi kuluar dari tepi. Lutut sedikit bengkok dan lengan menggantung rileks di sisi badan kemudian terjun dari kotak ketanah tanpa melompat dan mendarat ke tanah dengan kedua kaki dengan posisi lutut bengkok untuk meredam kejutan dari fase pendaratan.

Hal yang perlu diperhatikan segera setelah mendarat lakukan lompatan dengan mengayun lengan ke atas dan menjongkokkan setinggi mungkin untuk memperoleh lompatan yang optimal.(c). Power. Power adalah kemampuan seseorang untuk mempergunakan kemampuan otot tungkai untuk meloncat setinggi-tingginya dalam waktu yang sesingkat-singkatnya.(1). Asumsi (a). Adapun yang menjadi asumsi dalam penelitian ini adalah: (b). Subyek penelitian adalah pemain bolavoli putra di SMP N 5 Jember. (c). Orang coba dianggap atau diasumsikan mempunyai kebiasaan atau aktifitas yang sama diluar perlakuan 
penelitian. (1). Batasan masalah ruang lingkup penelitian ini terbatas pada: pengaruh latihan split squat jump dan depth jump terhadap peningkatan power otot tungkai.

Beberapa penelitian yang relevan tentang penerapan modifikasi permainan bola voli (Saputra \& Kurniawan, 2017) sedangkan tentang latihan menggunakan squat jump dan deep jump (Hadi, 2010) sedangkan latihan yang berpengaruh terhadap daya ledak yaitu latihan menggunakan plyometrik (Budhiarta, 2010), latihan menggunakan half squad dan quarter squat (Sulistyo, 2010), menggunakan latihan leadder drill (Pelamonia \& Harmono, 2018),

Tujuan dari penelitian ini adalah untuk mengetahui pengaruh latihan squat jump dan depth jum terhadap daya ledak serta untuk mengetahui latihan mana yang paling efektif. Penelitian ini dilakukan dengan melakukan perlakuan selama 2 bulan dengan perlakuan program latihan yang teratur yaitu selama 1 minggu melakukan latihan 3 kali. Studi ini dilakukan pada atlet bola voli putra pada SMPN 5 Jember.

\section{METODE PENELITIAN}

Jenis penelitian ini adalah kuantitatif, metode yang digunakan dalam penelitian ini adalah metode quasy eksperiment (Arikunto, 2006). Hal ini sebyek yang diteliti adalah manusia yang memiliki perbedaan aktifitas, bakat, motivasi, kondisi fisik, gizi, dan lingkiungan yang mempengaruhi hasil penelitian yang melibatkan dua variabel bebas yaitu : latihan split squat jump dan depth jump, serta satu variabel yang terkait yaitu tinggi loncatan power otot tungkai.

Desain penelitian yang akan digunakan dalam penelitian ini adalah pre-test post-tes groub design yang lebih jelasnya dapat digambarkan sebagai berikut :

$$
\begin{aligned}
& O_{1} \rightarrow x_{a} \rightarrow O_{2} \\
& O_{1} \rightarrow x_{b} \rightarrow O_{2}
\end{aligned}
$$

(Maksum, 2006)

\section{Gambar 1. Desain Penelitian}

Keterangan :

$\mathrm{O} 1$

: pretest tinggi loncatan

$\mathrm{O} 2$

: protest tinggi loncatan 
$\mathrm{Xa} \quad$ : perlakuan (pemberian latihan plyometric split squat jump)

$\mathrm{Xb}$ : perlakuan (pemberian latihan depth jump)

Penelitian ini dilaksanakan di SMP NEGERI 5 Jember dengan subyek penelitian adalah atlet bolavoli putra SMP NEGERI 5 Jember yang berjumlah 12 siswa. Jumlah sampel sebanyak 12 orang sehingga dalam penelitian ini merupakan sampel populasi.

Dalam penelitian ini subyek dibagi dua kelompok (kelompok split squat jump dan kelompok depth jump) setelah mengetahui hasil tes awal. Untuk menentukan dua kelompok digunakan cara ordinal pairing. Hakikat metode ini adalah pemisahan pasangan pasangan subyek (pair of subject). Pemisah ke grup I dan grup II secara otomatis menyeimbangkan kedua grup itu. Adapun pair of subject yang seimbang dijalankan atas dasar pre test.

Tabel 1. Pembagian Sampel Dengan Cara Ordinal Pairing

\begin{tabular}{cc}
\hline Kelompok I & Kelompok II \\
\hline 1 & 2 \\
4 & 3 \\
5 & 6 \\
8 & 7 \\
9 & 10 \\
12 & 11 \\
\hline
\end{tabular}

(Hadi, 2010)

Keterangan :

Kelompok I merupakan kelompok yang mendapatkan latihan split squat jump, sedangkan kelompok II merupakan kelompok yang diberi latihan depth jump. Masing masing kelompok mendapatkan perlakuan sama yaitu seminggu 3 kali selama 2 bulan. Data penelitian yaitu data kuantitatif yang berupa hasil tes berat badan, waktu meloncat dan tinggi loncatan dengan menggunakan jump median yang dilakukan 2 kali (pretest dan postest) dimana setiap siswa mendapat 3 kali kesempatan dalam setiap testnya dan kemudian nilai diambil dari hasil yang terbaik. 
Dalam penelitian ini informasi tentang pengaruh latihan plyometric split squat jump dan depth jump terhadap power otot tungkai diperoleh dengan menggunakan alat jump meter digital yang berfungsi untuk mengukur hasil tinggi loncatan. Teknik pengumpulan data yaitu dengan power otot tungkai diukur sebelum dan sesudah penelitian yaitu dengan melakukan tes lompat tegak sebanyak 3 kali dan diambil hasil yang terbaik. Teknik yang digunakan dalam analis data ini dibagi menjadi 3 bagian yaitu deskripsi data, uji persyaratan analisis, uji hipotesis.

\section{HASIL DAN PEMBAHASAN PENELITIAN}

Pada deskripsi data hasil penelitian ini membahas tentang rata-rata, simpangan baku dan varians yang diperoleh dari hasil tes latihan (perlakuan) yang diberikan pada masing-masing kelompok yaitu kelompok yang mendapat latihan split squat jump dan kelompok yang mendapat latihan depth jumph. Kemudian hasil tes tersebut akan dicatat dan dihitung berdasarkan kelompok dan jenis metode latihan yang diterapkan. Berdasarkan data tersebut selanjutnya akan dianalisa hasil dari kedua kelompok tersebut (kelompok split squat jump dan kelompok depth jump). Analisa menggunakan perhitungan SPSS 16.0 for windows selanjutnya deskripsi data dari hasil penelitian dapat dijabarkan lebih lanjut dalam bentuk tabel sebagai berikut :

Tabel 2. Deskripsi Data Pretest Kelompok Split Squat Jump

\begin{tabular}{ccccc}
\hline Split squat jump & N & Mean & Std. Deviation & Variance \\
\hline Pretest & $\mathbf{6}$ & $\mathbf{3 6 1 8}$ & $\mathbf{4 0 9 , 6 4}$ & $\mathbf{1 6 7 8}$ \\
\hline
\end{tabular}

Dari tabel 2 di atas dapat diketahui bahwa: Nilai rata-rata hasil tes power otot tungkai sebelum diberikan latihan split squat jump(pretest) sebesar 3618; dengan varian 1678; standart deviasi 409,64.

Tabel 3. Deskripsi Data Post Test Kelompok Split Squat Jump

\begin{tabular}{ccccc}
\hline $\begin{array}{c}\text { Split squat } \\
\text { jump }\end{array}$ & $\mathrm{N}$ & Mean & Std. Deviation & Variance \\
\hline Postest & 6 & 4095 & 317,24 & 1006
\end{tabular}


Dari tabel 3 di atas dapat diketahui bahwa : Nilai rata-rata hasil tes power otot tungkai sebelum diberikan latihan split squad jump (posttest) sebesar 4095 ; dengan varian 1006 ; standart deviasi 317,24.

Tabel 4. Deskripsi Data Pretest Kelompok Depth Jump

\begin{tabular}{ccccc}
\hline Depth jump & N & Mean & Std. Deviation & Variance \\
\hline Pretest & 6 & 3651 & 306,10 & 937
\end{tabular}

Dari tabel 4 di atas dapat diketahui bahwa : Nilai rata-rata hasil tes power otot tungkai sebelum diberikan latihan depth jump (pretest) sebesar 3651 ; dengan varian 937 ; standart deviasi 306,10.

Tabel 5. Deskripsi Data Post Test Kelompok Depth Jump

\begin{tabular}{ccccc}
\hline Depth jump & N & Mean & Std Deviation & Variance \\
\hline Posttest & 6 & 4121 & 331,56 & 10999
\end{tabular}

Dari tabel 4.4 di atas dapat diketahui bahwa nilai rata-rata hasil test power otot tungkai setelah diberikan latihan depth jump (postest) sebesar 4121 ; dengan varian 1099 ; standart deviasi 331,56. Maka dari itu, dapat diketahui bahwa ada perbedaan hasil tes dari kedua kelompok perlakuan tersebut (kelompok split squat jump dan depth jump). Hal ini terlihat dari nilai rata-rata post test lebih tinggi daripada nilai rata-rata pretest dari kedua jenis latihan (perlakuan) tersebut. Hal ini berarti bahwa pemberian perlakuan pada masing-masing kelompok (kelompok split squat jump dan kelompok depth jump) ternyata memberikan pengaruh terhadap peningkatan power otot tungkai pada atlet bola voli SMP Negeri 5 Jember.

Besarnya peningkatan power otot tungkai pada pemain bolavoli SMP Negeri 5 Jember pada masing-masing kelompok (kelompok split squat jump dan kelompok depth jump) bisa dilihat dari hasil perhitugan persentase kenaikan ratarata nilai antara pretest (sebelum dan sesudah mendapat perlakuan) seperti pada tabel berikut : 
Tabel 6. Hasil Perhitungan Persentase Peningkatan Power Otot Tungkai Pada Masing-Masing Kelompok

\begin{tabular}{cc}
\hline Nama kelompok & Jumlah \\
\hline Kelompok split squat jump & \\
Mean Deviasi & 476,50 \\
Mean Pretest & 3618,67 \\
Peningkatan & $13,17 \%$ \\
\hline Kelompok depth & \\
Mean Deviasi & 469,67 \\
Mean Pretest & 3651,67 \\
Peningkatan & $12,86 \%$ \\
\hline
\end{tabular}

Berdasarkan tabel 6 dapat dijelaskan bahwa peningkatan power otot tungkai kelompok pelatihan split squat jump sebesar 13,1\% lebih besar dari pada kelompok pelatihan depth jump yaitu sebesar 12,86\%. Hal-hal yang diperlukan untuk mengetahui analisis dalam penelitian ini adalah sebagai berikut:

1. Uji Normalitas

Untuk menguji kenormalan sebaran data, salah satunya dengan menggunakan perhitungan SPSS yaitu One-Sample Kolmogorov-Smirnov Test. Uji ini dilakukan dengan melihat nilai selisih yang diperoleh antara peluang komulatif dari observasi dengan peluang secara teoritis. Untuk menentukan apakah sebaran data normal atau tidak, dapat dilihat dari nilai Sig dibandingkan dengan nilai $\alpha$. Jika nilai $>\alpha$ maka data tersebut normal. Untuk lebih jelasnya dapat dilihat pada table uji normalitas menurut perhitungan SPSS dibawah ini.

Table 7. Ujian Normalitas

\begin{tabular}{cccc}
\hline Variabel & Sig & $\alpha$ & Keterangan \\
\hline Pre test kelompok 1 & 0,895 & 0,05 & Normal \\
\hline Pre test kelompok 1 & 1,000 & 0,05 & Normal \\
\hline Pre test kelompok 2 & 0,993 & 0,05 & Normal \\
\hline Pre test kelompok 2 & 1,000 & 0,05 & Normal \\
\hline
\end{tabular}

\section{Uji Homogenitas}

Untuk mengetahui apakah deskripsi data yang ada bersifat homogeny atau tidak dapat diketahui dengan cara perhitungan SPSS sebagai berikut:

a. Kelompok 1 
Tabel 8. Test of Homogeneity of Vareances

\begin{tabular}{cccc}
\hline Levene Statistic & df1 & df2 & Sig \\
\hline 1.027 & 1 & 10 & .335 \\
\hline Jadi data & & &
\end{tabular}
$(0,335>0,05)$

b. Kelompok 2

Tabel 9. Test of Homogeneity of Vareances

\begin{tabular}{cccc}
\hline Levene statistic & Df1 & Df2 & sig \\
\hline .008 & 1 & 10 & .931 \\
\hline
\end{tabular}

Jadi data yang digunakan adalah homogen, karena Sig lebih besar daripada $\alpha$ $(0,931>0,05)$

Berdasarkan deskripsi data penelitian dapat diketahui rata-rata latihan split squat jump para pemain bolavoli SMP Negeri 5 Jember untuk pretest sebesar 3618 watt dengan varians 1678 dan standart deviasi 409,64. Untuk posttest ratarata yang diperoleh adalah 4095 watt dengan varians 1006 dan standart deviasi 317,23 Sedangkan untuk rata-rata latihan depth jump atlet bolavoli SMP Negeri 5 Jember untuk pre test sebesar 3651 watt dengan varians 9370 dan standart deviasi 306,10. Untuk post test rata-rata yang diperoleh adalah sebesar 4121 watt dengan varians 1099 dan standart deviasi 331,.

Berdasarkan hasil uji t (paried t test) untuk masing-masing latihan terhadap peningkatan power otot tungkai sebelum pemberian latihan (pretest) dan setelah pemberian (posttest) menunjukkan bahwa: (a) nilai Sig untuk latihan split squad jump sebesar 0,001 lebih kecil dari pada $\alpha$ sebesar 0,05, dengan kata lain ada pengaruh yang signifikan pada latihan split squad jump untuk pretest dan postest terhadap peningkatan power otot tungkai pada pemain bolavoli SMP Negeri 5 Jember; dan (b) latihan depth jump sebesar 0,029 lebih kecil sebesar 0,05, dengan kata lain ada pengaruh yang signifikan pada latihan split squad jump untuk pretest dan postest terhadap peningkatan power otot tungkai pada atlet bola voli SMP Negeri 5 Jember ; dan (b) latihan depth jump sebesar 0,029 lebih kecil dari pada $\alpha$ $=0,05$, dengan kata lain ada pengaruh yang signifikan pada depth jump untuk pretest dan postest terhadap peningkatan power otot tungkai pada pemain bolavoli SMP Negeri 5 Jember. 
Sedangkan berdasarkan persentase peningkatan power otot tungkai (c) pelatihan split squat jump lebih baik daripada pelatihan depth jump yaitu 13,17\% dan $12,87 \%$ dan (d) berdasarkan uji dua kelompok (test) diperoleh nilai sig sebesar 0,892 lebih besar dari pada $\propto=0,05$, dengan kata lain tidak terdapat perbedaan antara latihan split squat jump dan depth jump dalam peningkatan power otot tungkai pada pemain bolavoli SMP Negeri 5 Jember

\section{SIMPULAN}

Berdasarkan pada latar belakang masalah, kajian pustaka, serta hasil penelitian yang telah diuraikan dalam bab sebelumnya maka metode latihan split squat jump dapat digunakan sebagai metode latihan yang efektif untuk meningkatkan power otot tungkai. Berdasarkan hasil analisis data yang telah diajukan, maka dapat disimpulkan bahwa :

1. Pelatihan split squat jump berpengaruh signifikan terhadap peningkatan power otot tungkai pada pemain bolavoli SMP Negeri 5 Jember.

2. Pelatihan depth jump berpengaruh signifikan terhadap peningkatan power otot tungkai pada pemain bolavoli SMP Negeri 5 Jember.

3. Pelatihan split squat jump lebih baik daripada pelatihan depth jump dalam peningkatan power otot tungkai pada pemain bolavoli SMP Negeri 5 Jember.

\section{DAFTAR PUSTAKA}

Adams, K., O’Shea, J. P., O’Shea, K. L., \& Climstein, M. (1992). The effect of six weeks of squat, plyometric and squat-plyometric training on power production. Journal of Strength and Conditioning Research. https://doi.org/10.1519/00124278-199202000-00006

Arikunto. (2006). Prosedur Penelitian: Suatu pendekatan Praktik. Jakarta: Rineka Cipta.

Barr, M. J., \& Nolte, V. W. (2011). Which measure of drop jump performance best predicts sprinting speed? Journal of Strength and Conditioning Research, 25(7), 1976-1982. https://doi.org/10.1519/JSC.0b013e3181e4f7ba

Budhiarta, M. D. (2010). Pengaruh Pelatihan Plyometrik Loncat Bangku 
Terhadap Daya Ledak Otot Tungkai Mahasiswa Jurusan PENJASKESREK FOK UNDIKSHA. Jurnal Healt and Sport, 1(1).

Hadi, R. (2010). Perbedaan Pengaruh Hasil Latihan Pliometrik Antara Squat Depth Jump Dan Jump To Box Terhadap Peningkatan Daya Ledak Otot Tungkai Pada Siswa EkstrakurikuleR Bolavoli SMP MTA Gemolong Sragen Tahun 2010. Universitas Sebelas Maret.

Hidayat, T. (2018). Pengaruh Latihan Plyometric Depth Jump Dan Jump To Box Terhadap Power Otot Tungkai Pada Pemain Ekstrakurikuler Bolavoli Smk Teknologi Nasional Malang. Jurnal Sport Science, 7(2).

Maksum, A. (2006). Ciri Kepribadian Atlet Berprestasi Tinggi. Disertasi, (January 2006). https://doi.org/10.13140/RG.2.2.18305.76646

Mushofi, Y. (2017). Pengembangan Model Latihan Passing Atas Bolavoli Di SMK Al Huda Wajak Malang. Jp.jok (Jurnal Pendidikan. Jasmani , Olahraga Dan Kesehatan), 1(1), 42-47.

Pelamonia, S. P., \& Harmono, B. A. (2018). Pengaruh Pelatihan Ladder Drill 90 Degree Rotation Dan Ladder Drill Ali Shuffle Terhadap Peningkatan Daya Ledak Otot Tungkai Dan Kecepatan. Jp.jok (Jurnal Pendidikan. Jasmani, Olahraga Dan Kesehatan), 2(1), 20-29.

Perikles, E. Y., Mintarto, E., \& Hasan, N. (2016). Pengaruh Latihan Jump To Box , Front Box Jump , dan Depth Jump Terhadap Peningkatan Explosive Power Otot Tungkai dan Kecepatan. Media Ilmu Keolahragaan Indonesia, 6(1), 814.

Ruswan, A. (2008). Pengaruh Beberapa Macam Metode Latihan Terhadap Peningkatan Kekuatan Otot. Bandung.

Santosa, D. W. (2015). Pengaruh Pelatihan Squat Jump Dengan Metode Interval Pendekterhadap Dayaledak (Power) Otot Tungkai. Kesehatan Olahraga.

Saputra, A. Y. D., \& Kurniawan, R. (2017). Penerapan Modifikasi Permainan Bolavoli Terhadap Hasil Belajar Siswa Dalam Pembelajaran Bolavoli. Jp.jok (Jurnal Pendidikan. Jasmani, Olahraga Dan Kesehatan), 1(1), 1-12.

Setiawan, D. (2013). Kondisi Fisik Pemain Sepakbola Klub Asyabaab Di Kabupaten Sidoarjo. Jurnal Kesehatan Olahraga, 1(1), 1-5.

Sulistyo, W. (2010). Pengaruh Latihan Half Squat dan Latihan Quarter Squat pada 
Kecepatan Tendangan dan Daya Ledak Otot Tungkai. Pendidikan Dan Kepelatihan Olahraga, 3(1). 